\title{
Digital educational environment as a factor of military professional training of future officers
}

\section{Ambiente educacional digital como fator de formação profissional militar de futuros oficiais}

\section{Entorno educativo digital como factor de formación profesional militar de futuros oficiales}

\author{
Marina Georgiyevna Sergeeva1 ${ }^{\text {iD }}$, Alexey Sergeevich Korobov² iD, Vladislav Borisovich Lukin² iD, \\ Egor Victorovich Paramonov² iD, Alexander Olegovich Zaitsev² iD \\ ${ }^{1}$ Research Institute of the Federal Penitentiary Service of Russia, Moscow, Russian. \\ ${ }^{2}$ Russian Air Force Military Educational and Scientific Center "Air Force Academy named after Professor N.E. Zhukovsky \\ and Y.A. Gagarin", Voronezh, Russian.

\section{Corresponding author:} \\ Marina Georgiyevna Sergeeva \\ Email: sergeeva198262@mail.ru
}

How to cite: Sergeeva, M. G., Korobov, A. S., Lukin, V. B., Paramonov, E. V., \& Zaitsev, A. O. (2021). Digital educational environment as a factor of military professional training of future officers. Revista Tempos e Espaços em Educação, 14(33), e15255. http://dx.doi.org/10.20952/revtee.v14i33.15255

\begin{abstract}
The safety and comfort of the digital educational environment in the professional training of future officers are interdependent parameters determining the psychological impact on both individuals and groups. For the development of a safe and comfortable educational environment, it is required to determine how the educational environment affects the personality, as well as how the personality determines the educational environment in higher education. The educational environment is a combination of material factors, interpersonal relations and specially organized psychological and pedagogical conditions for the development of a personality. The essence of the educational environment is represented as the interaction of its subsystems (local educational environments) and the creation of sustainable structure characteristic of a particular educational institution or educational system as a whole, which, on the one hand, influence the subjects of the educational environment, and on the other, are formed by them. The development of the educational environment is determined by both structural changes, such as changes in concepts, regulations and management, and personal changes in the participants of the educational process, in particular teachers and students. In practice, the educational environment consists of many local educational environments, which coexist, influencing each other.
\end{abstract}

Keywords: Higher education institution. Professional training. Future officer. Digital educational environment. Comfort and safety of training. 


\section{RESUMO}

A segurança e o conforto do ambiente educacional digital na formação profissional de futuros oficiais são parâmetros interdependentes que determinam o impacto psicológico tanto em indivíduos quanto em grupos. Para o desenvolvimento de um ambiente educacional seguro e confortável, é necessário determinar como o ambiente educacional afeta a personalidade, bem como como a personalidade determina o ambiente educacional no ensino superior. $\mathrm{O}$ ambiente educacional é uma combinação de fatores materiais, relações interpessoais e condições psicológicas e pedagógicas especialmente organizadas para o desenvolvimento de uma personalidade. A essência do ambiente educacional é representada como a interação de seus subsistemas (ambientes educacionais locais) e a criação de uma estrutura sustentável característica de uma determinada instituição de ensino ou sistema educacional como um todo, que, por um lado, influenciam os sujeitos do ambiente educacional e, por outro, são formados por eles. 0 desenvolvimento do ambiente educacional é determinado tanto por mudanças estruturais, como mudanças de conceitos, regulamentos e gestão, quanto por mudanças pessoais nos participantes do processo educacional, em particular professores e alunos. Na prática, o ambiente educacional consiste em muitos ambientes educacionais locais, que coexistem, influenciando-se mutuamente. Palavras-chave: Instituição de ensino superior. Treinamento profissional. Futuro oficial. Ambiente educacional digital. Conforto e segurança do treinamento.

\section{RESUMEN}

La seguridad y comodidad del entorno educativo digital en la formación profesional de los futuros agentes son parámetros interdependientes que determinan el impacto psicológico tanto en los individuos como en los grupos. Para el desarrollo de un entorno educativo seguro y confortable, se requiere determinar cómo el entorno educativo afecta a la personalidad, así como cómo la personalidad determina el entorno educativo en la educación superior. El entorno educativo es una combinación de factores materiales, relaciones interpersonales y condiciones psicológicas y pedagógicas especialmente organizadas para el desarrollo de una personalidad. La esencia del entorno educativo se representa como la interacción de sus subsistemas (entornos educativos locales) y la creación de una estructura sustentable característica de una determinada institución educativa o sistema educativo en su conjunto, que, por un lado, influyen en los sujetos de la educación. entorno educativo, y por otro, están formados por ellos. El desarrollo del entorno educativo está determinado tanto por cambios estructurales, como cambios de conceptos, normativas y de gestión, como por cambios personales en los participantes del proceso educativo, en particular docentes y alumnos. En la práctica, el entorno educativo se compone de muchos entornos educativos locales, que coexisten e influyen mutuamente.

Palabras clave: Institución de educación superior. Entrenamiento profesional. Futuro oficial. Entorno educativo digital. Confort y seguridad del entrenamiento.

\section{INTRODUCTION}

To understand the essence of the educational environment and its characteristics, it is necessary to consider the environment as a general concept, as well as to extrapolate the basic properties of environment to the educational sphere, in particular, such properties as the systemic emergence effect, the hierarchy of structural components, the possibility of development in changing conditions, etc. The safety and comfort are structural components and indicators of the educational environment. The educational environment determines the psychological safety and comfort of both an individual participant in the educational process and groups. These parameters reflect the nature and characteristics of relationships within the educational environment, therefore, are entirely determined by the management system of the educational organization (Volkova \& Panchenko, 2018). 
The educational environment is a combination of material factors of the educational process, interpersonal relations and specially organized psychological and pedagogical conditions for the development of a personality. Since, in practice, the educational environment consists of many local environments, then in the same educational institution local environments with different modality can coexist, influencing each other. Therefore, to understand the essence of the educational environment and its key characteristics, it is necessary to consider the environment as a general concept, as well as extrapolate the basic properties of the environments to the education (Gorev et al., 2018).

The review of the related literature (Wang et al., 2018; Utenov et al., 2018; Sharonova et al., 2018; Sergeeva et al., 2017; 2018; 2019; Vasilyeva \& Sokolova, 2017) confirmed that the safety and comfort of the educational environment are inextricably linked with each other and describe, first of all, the psychological aspect of the educational environment, its influence on personality and reference groups. We consider the psychological safety and comfort of the educational environment as the most important conditions for giving it a developing character.

\section{LITERATURE REVIEW}

Education, as one of the most important social institutions, is undergoing significant changes, primarily due to the emergence of new socio-philosophical paradigms. New technological and methodological principles and approaches are the foundation for the emergence of new technologies, primarily information and communication (Neverkovich et al., 2018; Sergeeva et al., 2019).

Considering the relationship between the new philosophical paradigms and technologies in more detail, we used the example of the relationship between the philosophy of anthropocentrism and communicative technologies in education. For a consistent and detailed study of this relationship, we should pay attention to the essence of the above paradigms and their significance for modern education.

First of all, the humanistic philosophy of Carl Rogers should be noted as the philosophical foundation of modern education, since this concept is the basis for the genesis of the anthropological approach, as well as such paradigms as (Sergeeva et al., 2018):

- Wolfgang Klafki concept of critical-constructive didactics;

- the Frankfurt School of social theory and critical philosophy guided by Jürgen Habermas;

- ideas of critical pedagogy (Paulo Freire, Peter McLaren);

- postmodern tendencies in the philosophy of education.

The ideas of $\mathrm{C}$. Rogers formed the basis of the key concepts, the cornerstones, on which the modern educational system is based - subject-to-subject interaction as the basis of the educational process, the interaction between teacher and student (Dolzhich \& Dmitrichenkova, 2018).

The humanistic ideas of $C$. Rogers created the preconditions for the humanization and democratization of the new forms of the educational environment, and the implementation of anthropocentric approach in education. So, for example, postmodern trends in education, such as inclusive education, gender equality, etc., are based on the humanistic philosophy.

The implementation of principles of humanism and anthropocentrism in pedagogical practice has changed the understanding of the communication in the educational space. The development of new philosophical and scientific ideas about pedagogical interaction gave rise to modern communication technologies in education. The argument in favor of the above thesis is the modern understanding of pedagogical communications as the interaction of subjects and all parties involved.

Next, we paid attention to how modern communication theory, as well as communication philosophy, is implemented in the context of education. It is important to note that one of the key terms of the modern communication concept is discourse. This concept is characteristic of 
postmodern philosophy, postulating the equivalence of opinions and the subjectivity of knowledge (Vasbieva et al., 2018).

In practice, this is expressed in the fact that communications are not aimed at any ideal result or standard, but at revealing the individuality of the subjects. From the point of view of Russian educator L.L. Balakina, this thesis is consistent with one of the most important functions of education - the developmental function, since as a result of such communications, we create an opportunity to reveal the potential of a student, to develop his/her personality (Baeva, Tarasova, 2014). Communication in this context has a significant positive impact on the socialization of the student (Blinova et al., 2018). Having designated the key aspect of the theory of communications, with regard to the problems of this research, we proceed directly to the analysis of communication technologies in education.

Communication technologies are the technologies aimed at optimizing interactions between subjects. Often communicative technologies are assimilated to the information technologies that significantly increase the efficiency of communications, as well as the interactive technologies that optimize the transmission and perception of information. In Russian education, these technologies are referred as a special set of technologies - information and communication technologies (ICT), since it is difficult to distinguish between them (Bírová et al., 2018). In interactive education, communication technologies are used extremely widely, both in educational and managerial processes, internal and external communications, etc.

From the practical point of view, the optimization of the educational environment is determined by the level of socio-psychological adaptation of its participants. Therefore, an important task is to promote the socio-psychological adaptation of first-year students (Sergeeva et al., 2018).

Socio-psychological adaptation to a new educational and social environment, the creation of a friendly atmosphere helps to relieve tension and nervousness that destroy the mental and physical health of students. The adaptation of first-year students is the most significant aspect of creating a safe and comfortable educational environment in higher education institutions, since this youth group is the most sensitive.

\section{METHODOLOGY}

The experimental research was carried out on the basis of the Department of Pedagogy, Psychology, Law, History and Philosophy of the Mytischi Branch (MB) of Bauman Moscow State Technical University in the $2019 / 2020$ academic year.

The experiment involved 55 participants ( 20 teachers and 35 students of the faculty). The study used a diagnostic approach to assessing the effectiveness of the educational environment proposed by I.A. Baeva $(2002 ; 20140)$. In the course of this study, a program for improving the safety and comfort of the educational environment of the HEls was developed, based on digital technologies, in particular, digital monitoring and distance learning technologies.

The purpose of the program is to create conditions for successful socio-psychological adaptation and self-actualization of first-year students. The program is detailed in Table 1.

The purpose is due to the fact that these students demonstrate, on the one hand, the greatest susceptibility to the negative impacts of the educational environment, and on the other hand, the lowest indicators of psychological comfort and a sense of security.

On that account the main efforts during the implementation of the program are aimed at first-year students. Important areas of activity involve the teaching staff in order to optimize their activities, increase the communicative competence of beginning teachers with less than 3 years of experience, and the administrative staff of the faculty.

Thus, the program is focused on three parties of the educational process - students, teaching and administrative staff. 
Program objectives:

1) development and implementation of psychological and correctional measures;

2) development of the ideas of teaching and administrative staff about the essence of the educational environment, the structure of the educational process, extracurricular activities among students,;

3) development of group cohesion, team-building, favorable psychological climate in the teaching, student and administrative staff;

4) development of effective interpersonal skills, increasing self-confidence among all participants.

Table 1. Content of the training program "Organizing a psychologically comfortable and safe educational environment in HEls".

Training sessions Contents Duration

Training session 1 Introduction. 20 minutes

Acquaintance with first year students, description of the purpose, focus of training.

Training session 2 1. Conducting primary psycho-diagnostics of the educational environment,30 minutes participants of the educational process.

Testing 1.

2.Mini-lecture on effective communication to the teaching staff. 30 minutes

3. Mini-lecture on managing interactions to the administrative staff. 30 minutes

4. Simulation game with students "My idea of the future profession".

40 minutes

Training session 3 1. Analysis of the primary psycho-diagnostics results, discussion with students. 30 minutes

2. Team-building training session with students in order to increase group cohesion.1 day A ropes course.

3. Training session with teachers 40 minutes

"Emotional weight of pedagogical interaction".

4. Mini-lecture to teachers "The essence and structure of the educational 30 minutes environment of the university".

Training session 4 1. Conducting intermediate psycho-diagnostics of the educational environment,40 minutes participants of the educational process. Testing 2.

2. Individual counseling for students with a low level of psychological comfort and60 minutes adaptation.

3. Role-playing game with students "Role reversal".

30 minutes

Training session 5 1. Mini-lecture to teachers "Ensuring the safety of the educational environment". 30 minutes

2. Mini-lecture to the administrative staff "The role of safety and comfort in the 30 minutes educational environment for ensuring the quality of education".
3. Panel discussion with students.
60 minutes
"Advantages and disadvantages of student life".

Training session 6 1. Training for teachers "Establishing contact in communication".

40 minutes

2. Training for students to improve their self-esteem.

40 minutes

3. Role-playing game "How I would organize the education in the University".

60 minutes

Training session 7 1. Individual counseling for students. 60 minutes

2. Mini-lecture to students "Time-management". 30 minutes

3. Mini-lecture to teachers "Ensuring the comfort of the educational environment".30 minutes

4. Panel discussion with students "How to realize yourself".

60 minutes

Training session 8 1. Conducting intermediate psycho-diagnostics of the educational environment,40 minutes participants of the educational process. Testing 3.

2. Mini-lecture to students "Conflict and ways to overcome it".

30 minutes

3. Training for teachers "Self-confidence and communication efficiency".

45 minutes 


\begin{tabular}{|c|c|c|}
\hline \multirow[t]{2}{*}{ Training session 9} & $\begin{array}{l}\text { 1. Role-playing game with students } \\
\text { "I am a graduate". }\end{array}$ & 40 minutes \\
\hline & 2. Mini-lecture to students "Self-education". & 30 minutes \\
\hline \multicolumn{2}{|c|}{ Training session 101. Individual counseling for students. } & 60 minutes \\
\hline & 2. Training with students to improve self-esteem "The motives of my actions". & 45 minutes \\
\hline & $\begin{array}{l}\text { 3. Mini-lecture to teachers } \\
\text { "Algorithms for Optimizing the Educational Environment". }\end{array}$ & 30 minutes \\
\hline & $\begin{array}{l}\text { 4. Mini-lecture to administrative staff "Monitoring the educational environmen } \\
\text { the HEls". }\end{array}$ & 30 minutes \\
\hline \multicolumn{2}{|c|}{ Training session 111. Individual counseling for students. } & 60 minutes \\
\hline & \multicolumn{2}{|c|}{$\begin{array}{l}\text { 2. Training for students to improve the efficiency of communication "Laws of } 40 \text { minutes } \\
\text { effective communication". }\end{array}$} \\
\hline & \multicolumn{2}{|c|}{$\begin{array}{l}\text { 3. Training for teachers to improve the effectiveness of interaction "Perception of } 40 \text { minutes } \\
\text { the interlocutor". }\end{array}$} \\
\hline \multicolumn{3}{|c|}{$\begin{array}{l}\text { Training session } \begin{array}{l}\text { 121. Conducting final psycho-diagnostics of the educational environment, participants } 45 \text { minutes } \\
\text { of the educational process. } \\
\text { Testing } 4 .\end{array}\end{array}$} \\
\hline & 2. Summing up the optimization program. & 20 minutes \\
\hline & \multicolumn{2}{|c|}{$\begin{array}{l}\text { 3. Consultations with the administrative and teaching staff on the continuation of } 60 \text { minutes } \\
\text { activities to optimize the educational environment of the faculty. }\end{array}$} \\
\hline
\end{tabular}

The short-term interpersonal communication trainings aimed at increasing the effectiveness of interaction are held with students, teaching and administrative staff. In-depth psychocorrectional training is carried out, if necessary, with first-year students who have a very low level of adaptation and psychological comfort.

Optimization of the educational environment, comfort and safety results from improving the efficiency of interaction between the teaching and administrative staff, both among themselves and with students. The program is focused on 12 sessions with students and 6 sessions with teaching and administrative staff. Training sessions are held in a group, free form, no more than 90 minutes, so as not to overload the educational process.

\section{RESULTS AND DISCUSSION}

In this research we used a diagnostic approach to assessing the effectiveness of the educational environment proposed by I.A. Baeva, which contains three main aspects:

1) analysis of structural components;

2) studying the impact of the environment on its participants (as a rule, on students and, to a much lesser extent, on teachers and other participants);

3) a combination of the first two (Apisheva, 2016).

To analyze the diagnostic results obtained at the indicative stage of the experiment, the method of absolute scales was used, which allowed, with a slight error (no more than $2.5 \%$ ), to carry out a comparative analysis of the data obtained in different measurement systems and having different criteria for assessing their significance. The difference between the measurement scales and the system for evaluating the experimental results justifies the use of this method.

A generalized scale of measurements from 1 to 100 was used, the criteria for assessing the significance: 1 - 45 - low level; 45 - 70 - intermediate level; 70 - 100 - high level. The average values of the indicators and the deviation from the average were obtained and analyzed. We paid special attention to the results of diagnostics of the management efficiency. The results are shown in table 2. 
Table 2. Efficiency of administrative management.

\begin{tabular}{ll}
\hline Parameter & Efficiency of administrative management \\
\hline From the point of view of teaching staff & 80.4 \\
From the point of view of students & 83.7 \\
\hline
\end{tabular}

The analysis of the data presented in table 2 allows us to conclude that the efficiency of administrative management is high both from the point of view of teachers and from the point of view of students. The style of management is democratic, which means developed feedbacks between administration, students and teachers. The results of diagnostics prove that the administration is equally sensitive to the problems of teachers and students, which confirms its positive impact on the educational environment of the university.

The results of diagnostics of the safety and comfort of the educational environment by the method of I.A. Baeva are shown in figure 1. The indicators presented in figure 1 reflect the safety of the educational environment for both teachers and students.

The diagnostics allows us to concretize the indicators of safety and comfort separately for students and teachers, as participants in the educational environment.

Figure 1. Results of the diagnostics of safety and comfort of the educational environment at the indicative stage of the experiment.

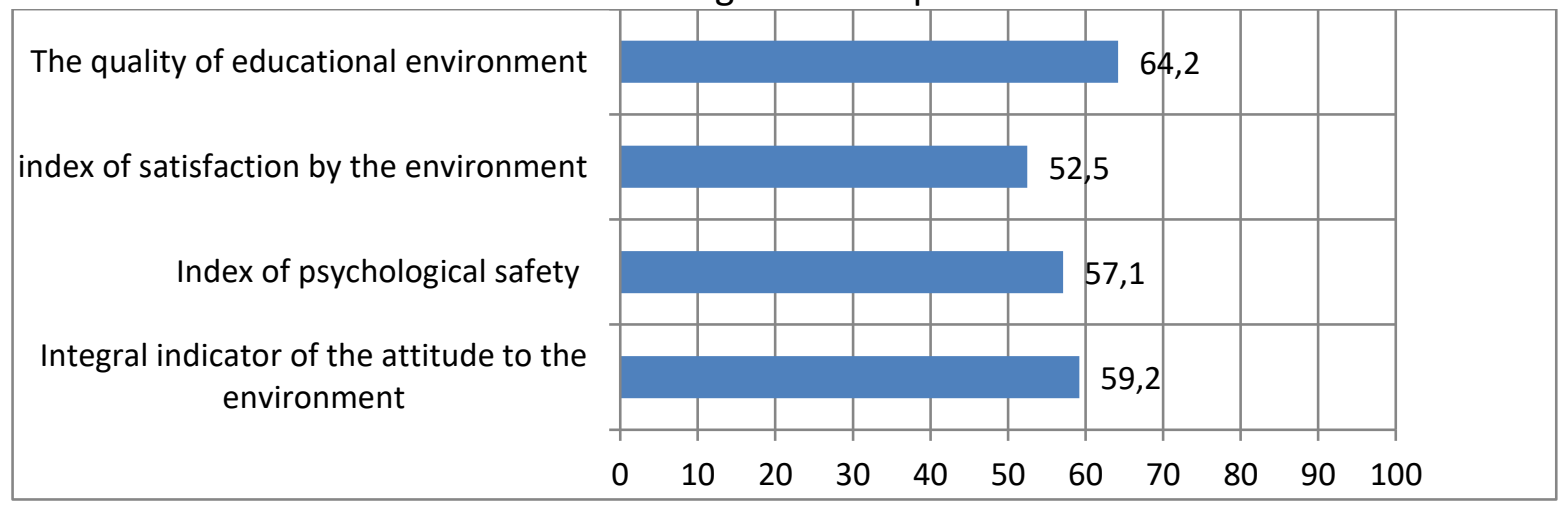

Analysis of the data presented in Figure 1 shows that the university has an intermediate level of safety and comfort of the educational environment. It is important to pay attention to the fact that only 1 parameter, which determines the quality of the educational environment, is close to the high range of values. Diagnostic data indicate that the educational environment of the university is characterized by an intermediate level of psychological safety and comfort.

Next, we considered the results of diagnosing the safety and comfort of the educational environment in a differentiated way for teachers and students. The results are shown in figure 2.

Figure 2. The results of diagnostics of the safety and comfort of the educational environment in a group of university teachers at the indicative stage of the experiment.

The quality of education environment

Index of satisfaction by the environment

Index of psychological safety

Integral indicator of the attitude to the environment

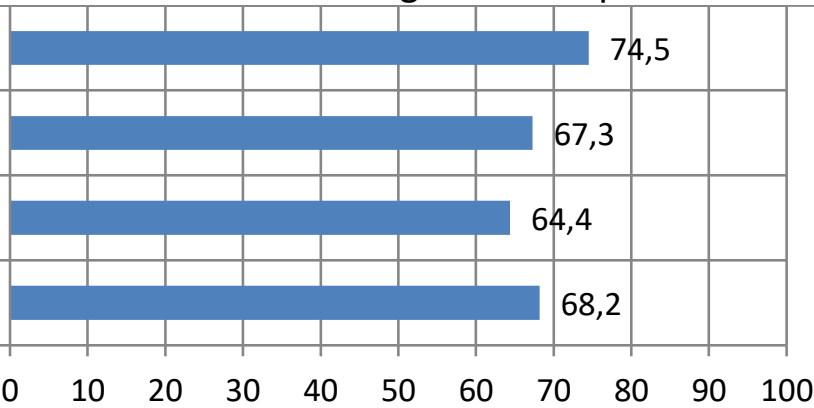


Analysis of the data presented in figure 2, allows us to conclude that for teachers the safety and comfort of the educational environment is favorable, since the indicators are close to the high range of values, and the quality of the educational environment demonstrates a high level of development.

Figure 3. The results of diagnostics of the safety and comfort of the educational environment in a group of university students at the indicative stage of the experiment.

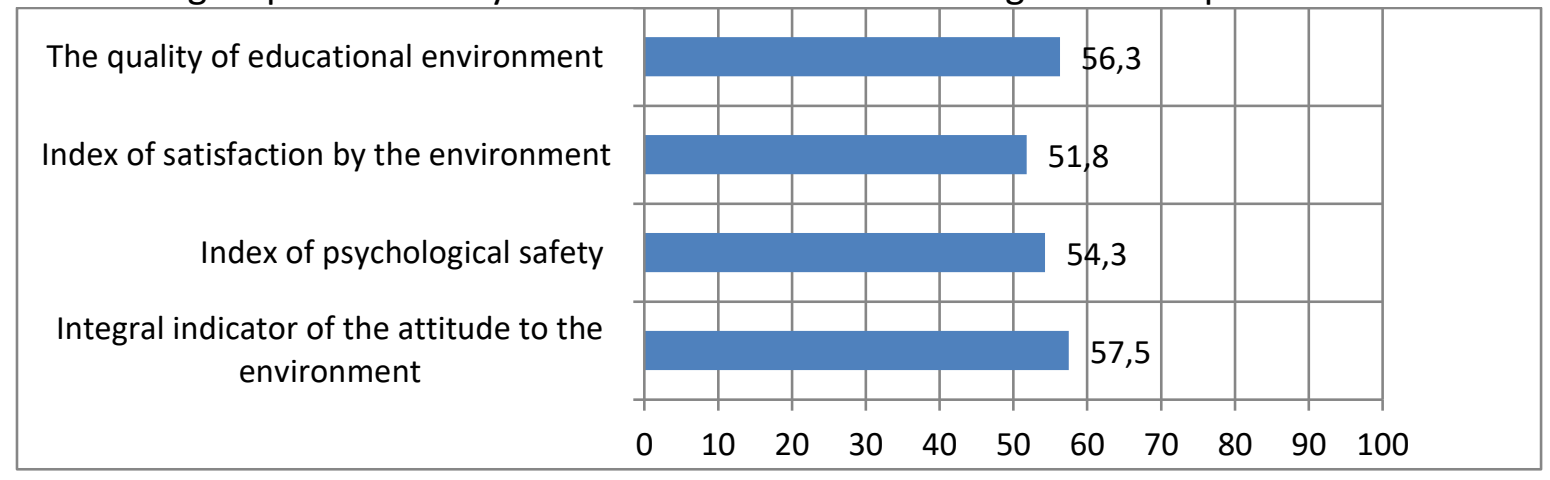

Analysis of the data presented in figure 3 indicates that for students the safety and comfort of the educational environment is relatively favorable, since the indicators are in the range of intermediate values.

Comparison of the indicators of students with the indicators of teachers and general indicators for the university revealed that the educational environment is more favorable, safe and comfortable for teachers, and less favorable, safe and comfortable for students.

It should be noted that considering the opinions of students, we revealed a tendency indicating that the safety and comfort of the educational environment depends on the duration of students' studies. The results are shown in table 3.

Table 3. Indicators of deviation of the values of diagnostics from the average values (Figure 3), based on the duration of training of students (year of study) at the indicative stage of the experiment.

\begin{tabular}{|c|c|c|c|c|}
\hline Parameters & 1 year & 2 year & 3 year & 4 курс \\
\hline $\begin{array}{l}\text { Integral indicator of the attitude } \\
\text { to the environment }\end{array}$ & -22.7 & -2.1 & +8.2 & +11.7 \\
\hline Index of psychological safety & -19.3 & -1.6 & +7.1 & +10.9 \\
\hline $\begin{array}{l}\text { Index of satisfaction by the } \\
\text { environment }\end{array}$ & -18.5 & -0.7 & +6.3 & +11.1 \\
\hline $\begin{array}{l}\text { The quality of the educational } \\
\text { environment }\end{array}$ & -19.1 & -1.8 & +7.6 & +10.3 \\
\hline
\end{tabular}

Analysis of the data presented in table 3 allows us to conclude that the shorter the duration of a student's study at a university, the less safe and comfortable the educational environment for a given subject. This tendency is explained by the fact that the greatest deviation from the average for students' indicators is observed on the 1st year (downward) and on the 4th year (upward).

The relationship is confirmed by correlation analysis, $t=0.714$ at $p \leq 0.01$ according to Student's tests.

Critically significant deviations are associated, first of all, with a low degree of adaptation of first-year students to university studies in comparison with senior students.

The revealed trend indicates that the optimization of the safe and comfort educational environment of the university should primarily be aimed at 1st year students, whose safety and comfort are the least. 
In order to determine the parameters for optimizing the safety and comfort of the educational environment for the most sensitive subjects of the educational environment (1st year students), we should pay attention to the diagnostics of parameters that significantly affect the safety and comfort of the educational environment. The results are shown in figure 4.

Figure 4. The results of diagnostics of communicative competence, the level of self-actualization, stress resistance and anxiety of teachers (in general) at the indicative stage of the experiment.

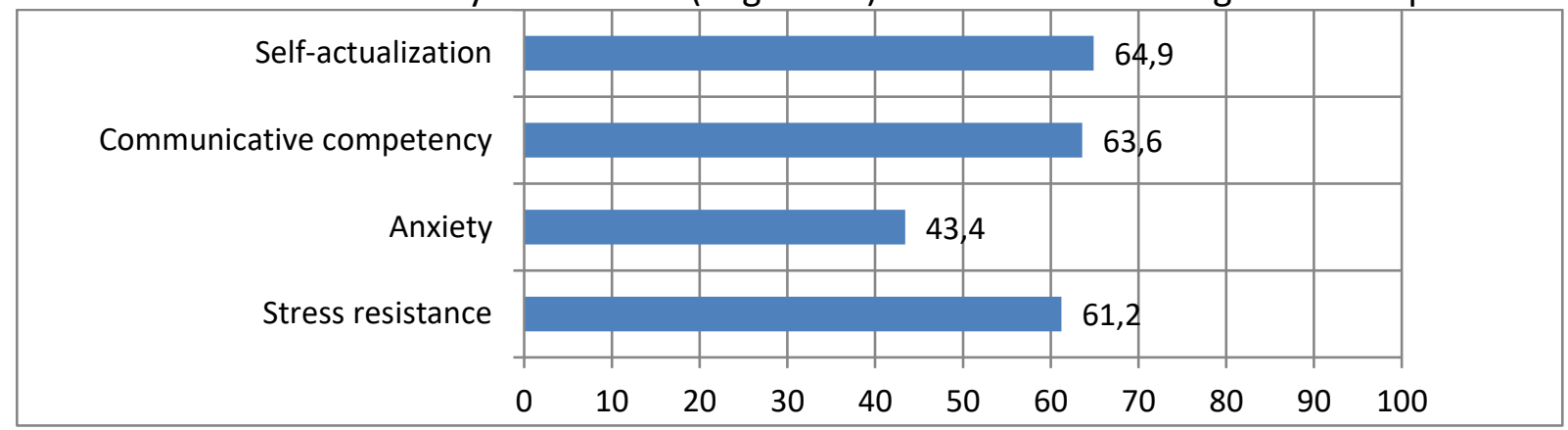

\section{CONCLUSION}

The program of organizing a psychologically comfortable and safe educational environment of the HEls is aimed at developing the declared parameters and working with all significant subjects of the educational environment: teachers, students and administration. The program includes training sessions, mini-lectures and other forms for the effective organization of a psychologically comfortable and safe environment.

Analysis of the experimental results proved that the proposed program is highly effective, maximizing the levels of comfort and safety of the educational environment, relative to all its subjects. Indicators of safety and comfort of the educational environment increased significantly at the control stage of the experiment. More than $25 \%$ growth of indicators was noted, each of the indicators of the educational environment reached the high range of values.

\section{REFERENCES}

Apisheva, A.Sh. (2016). Psychological Safety Of Teachers In The Educational Environment Of A Higher Educational Institution. Society: Sociology, Psychology, Pedagogy, 3, 48-51.

Araujo, A., \& Silva, I. P. (2020). Maker culture and educational robotics in physics teaching: developing an automated traffic light in high school. Journal of Research and Knowledge Spreading, 1(1), e11654.

Baeva, I.A. (2002). Psychological Safety In Education. St. Petersburg: Izdatel'stvo "SOYUZ".

Baeva, I.A., Tarasova, S.V. (2014). Safe Educational Environment: Psychological And Pedagogical Foundations Of Formation, Maintenance And Assessment: Monograph. St. Petersburg: State Autonomous Educational Institution Of Additional Professional Education "Leningrad Regional Institute Of Education Development.

Bírová, J., Kružlík, P., Kalimullin, A., Sokolova, N., Haroun, Z., Králik, R., Vasbieva, D. (2018). Mathematical And Statistical Bibliometric Indicators For Scholars In The Field Of Romance Languages And Linguistics. Eurasia Journal Of Mathematics, Science And Technology Education, 14(12), Em1638.

Blinova, S., Dugina, T., Zabolotskikh, A. (2018). Teaching Mixed Nationality Groups (On The Example Of Students From The Northern Caucasus Region). In: INTED2018: Proceedings Of The 12th International Technology, Education And Development Conference (Pp. 7977-7982). Valencia: IATED.

Dolzhich, E., Dmitrichenkova, S. (2018). Computer Science Terminology (A Case Study Of The Spanish Language). In: INTED2018: Proceedings Of The 12th International Technology, Education And Development Conference (Pp. 25562559). Valencia: IATED.

Gorev, P., Telegina, N., Karavanova, L., Feshina, S. (2018). Puzzles As A Didactic Tool For Development Of Mathematical Abilities Of Junior Schoolchildren In Basic And Additional Mathematical Education. Eurasia Journal Of Mathematics, Science And Technology Education, 14(10), 178-185. 
Neverkovich, S., Bubnova, I., Kosarenko, N., Sakhieva, R., Sizova, Zh., Zakharova, V., Sergeeva, M. (2018). Students' Internet Addiction: Study And Prevention. Eurasia Journal Of Mathematics, Science And Technology Education, 14(4), 1483-1495.

Oliveira, A. M., Gerevini, A. M., \& Strohschoen, A. A. G. (2017). Diário de bordo: uma ferramenta metodológica para o desenvolvimento da alfabetização científica. Revista Tempos e Espaços em Educação, 10(22), 119-132.

Rodrigues, B. M., Santos, J. E. B., \& Vasconcelos, C. A. (2020). Conceptions of undergraduate students in Chemistry on the use of interactive interfaces in and for the activities developed in the distance course. Journal of Research and Knowledge Spreading, 1(1), e11649.

Santos, J. E. B. (2020). Cartographic narratives: the teaching of mathematics and ICT. Journal of Research and Knowledge Spreading, 1(1), e11645.

Sergeeva, M., Bondarenko, N., Shebzuhova, T, Vartumyan, A., Lesnikova, S. (2018). Scientific Substantiation Of The Conception Of Continuous Economic Education Development. Turkish Online Journal Of Design Art And Communication (TOJDAC), 8, 178-185.

Sergeeva, M., Shumeyko, A., Serebrennikova, A., Denisov, A., Bondarenko, N., Getmanova, E. (2018). Innovative Pedagogical Experience In Practice Of Modern Education Modernization. Modern Journal Of Language Teaching Methods, 8(11), 814-823.

Sergeeva, M.G., Bondarenko, N.G., Shebzuhova, T.A., Solovyov, B.A., Parinov, D.V., Shvedov, L.A., Ovchinnikov, A.P. (2019). Verification Of Management-Support Of Professional And Educational Trajectory Of Students In The SocioCultural Educational Environment Of The University. Amazonia Investiga, 8(18), 5-14.

Sergeeva, M.G., Flyagina, V.Yu., Taranenko, I.V., Krasnova, E.V., Vilkova, A.V. (2017). The Interaction Of Labour Market And Educational Services Market Considering Social Partnership Mechanism And Specificity Of Regional Educational Policy. Ponte, 73(12), 2.

Sergeeva, M.G., Gubarkov, S.V., Zhigalov, K.Yu., Kurmaeva, I.I., Tolmachev, A.V. (2018). Quality Management Of Services Of The Higher Education. Ponte, 74(1), 34-47.

Sergeeva, M.G., Stepanyan, T.M., Spector, A.A., Komov, M.S., Latysheva, N.A., Okhotnikov, I.V., Shvedov, L.A. (2019). Formation Of Economic Competence Of The Head Of The Educational Organization In Terms Of Professional Development. Revista San Gregorio, 30, 7-13.

Sharonova, S., Trubnikova, N., Sokolova, N. (2018). Interpreting Religious Symbols As Basic Component Of Social Value Formation. European Journal Of Science And Theology, 14(3), 117-129.

Utemov, V., Khusainova, R., Sergeeva, M., Shestak, V. (2018). Full Packaged Learning Solutions For Studying Mathematics At School. Eurasia Journal Of Mathematics, Science And Technology Education, 14(12), Em1619.

Vasbieva, D.G., Sokolova, N.L., Masalimova, A.R., Shinkaruk, V.M., Kiva-Khamzina, Y.L. (2018). Exploring The EFL Teacher's Role In A Smart Learning Environment - A Review Study. Xlinguae, 11(2), 265-274.

Vasilyeva, I.I., Sokolova, N.L., Mikheeva, N.F. (2017). Some Trends In The Use Of ICT In Russian Scientific Research In The Field Of Teaching Foreign Languages And Translation In Universities (2012-2017). Problems Of Applied Linguistics, 27, 7-18.

Volkova, Y., Panchenko, N. (2018). Discourse Variation Of The Concepts Of Destructive Emotions. Vestnik Rossiiskogo Universiteta Druzhby Narodov. Russian Journal Of Linguistics, 22(1), 175-194.

Wang, S., Gorbunova, N., Masalimova, A., Bírová, J., Sergeeva, M. (2018). Formation Of Academic Mobility Of Future Foreign Language Teachers By Means Of Media Education Technologies. Eurasia Journal Of Mathematics, Science And Technology Education, 14(3), 959-976.

Received: 8 January 2021 | Accepted: 6 February 2021 | Published: 16 February 2021

This is an Open Access article distributed under the terms of the Creative Commons Attribution License, which permits unrestricted use, distribution, and reproduction in any medium, provided the original work is properly cited. 